\begin{tabular}{lc}
\hline JURNAL ANALIS KESEHATAN \\
KNIVERSITAS \\
KBDURRAB
\end{tabular}

\title{
Identifikasi Telur Nematoda Usus Soil Transmitted Helminth Pada Feses dan Kotoran Kuku Petani Sawah di Desa Munggur Kecamatan Manyaran Wonogiri
}

\author{
Anggi Seftiana Damayanti, Tri Mulyowati
}

\author{
Program Studi D3 Analis Kesehatan, Fakultas Ilmu Kesehatan \\ Universitas Setia Budi Jalan Letjen Sutoyo Surakarta \\ trimulyowati@setiabudi.ac.id
}

\section{Info Artikel \\ Sejarah Artikel: \\ Diterima November 2021 \\ Disetujui Desember 2021 \\ Dipublikasikan Desember 2021}

Keywords:

Keyword; Keyword; Keyword
Soil Transmitted Helminth (STH) merupakan nematoda usus penyebab infeksi kecacingan yang ditularkan melalui tanah untuk perkembangan menjadi bentuk infektif. Spesies yang termasuk nematoda usus golongan STH yaitu Ascaris lumbricoides, Trichuris trichiura, Ancylostoma duodenale, Necator americanus dan Strongyloides stercoralis. Manusia dapat terinfeksi apabila tidak sengaja menelan telur cacing atau melalui penetrasi kulit akibat kontak langsung dengan tanah tanpa APD. Tujuan dari penelitian ini adalah untuk mengetahui persentase petani sawah di Desa Munggur Kecamatan Manyaran Wonogiri yang terinfeksi nematoda usus STH. Metode penelitian ini menggunakan metode jenis observasional dengan pendekatan cross sectional. Pemeriksaan pada sampel feses menggunakan metode langsung dengan larutan $\mathrm{NaCl} 0,9 \%$ dan larutan lugol 1-2\%, sedangkan sampel kuku menggunakan metode sedimentasi dengan larutan $\mathrm{NaOH} \quad 0,25 \%$ ditambah larutan lugol 1-2\%. Hasil pemeriksaan pada sampel feses ditemukan adanya telur nematoda usus STH, sedangkan pada kotoran kuku tidak ditemukan adanya telur nematoda usus STH. Simpulan penelitian ini adalah adanya telur nematoda usus STH pada sampel feses nomor 12,13 dengan ditemukannya telur Hookworm. Persentase hasil pemeriksaan pada sampel feses dinyatakan positif sebesar $10 \%$ sedangkan sampel kotoran kuku dinyatakan positif $0 \%$.

Kata kunci : Soil Transmitted Helminth, feses, kotoran kuku.

.Abstract

Soil Transmitted Helminth (STH) is an intestinal nematode that causes helminth infections that are transmitted through soil to develop into an infective form. Species belonging to the intestinal nematodes of the STH group are Ascaris lumbricoides, Trichuris trichiura, Ancylostoma duodenale, Necator americanus and Strongyloides stercoralis. Humans can 
be infected by accidentally ingesting worm eggs or through skin penetration due to direct contact with soil without personal protective equipment. The purpose of this study was to determine the percentage of rice farmers in Munggur Village, Manyaran Wonogiri District who were infected with the intestinal nematode STH..This research method uses an observational method with a cross sectional approach. Examination of the stool samples used the direct method with $0,9 \% \mathrm{NaCl}$ solution and 1-2\% Lugol solution, while the nail samples used the sedimentation method with $0,25 \% \mathrm{NaOH}$ solution plus $1-2 \%$ Lugol solution. The results of the examination on the stool samples found the presence of STH intestinal nematode eggs, while in the nail feces no STH intestinal nematode eggs were found. The conclusion of this study was the presence of STH intestinal nematode eggs in stool sample number 12.13 with the discovery of Hookworm eggs. The percentage of examination results on stool samples was declared positive at $10 \%$ and negative stool samples were stated negative at $90 \%$, while nail dirt samples were declared positive at $0 \%$ and negative samples were stated at $100 \%$.

Keywords: Soil Transmitted Helminth, feces, nail dirt

(C) 2021

Universitas Abdurrab

Alamat korespondensi: ISSN 2338-4921

Program Studi D 3 Analis Kesehatan,

Fakultas Ilmu Kesehatan Universitas

Setia Budi Jalan Letjen Sutoyo Surakarta

Email.trimulyowati@setiabudi.ac.id

\section{PENDAHULUAN}

Infeksi Soil Transmitted Helminth (STH) merupakan penyakit tropis (neglected tropical disease) dan menjadi masalah kesehatan yang masih terabaikan karena tidak secara langsung menimbulkan dampak yang nyata (Prabandari et al., 2020). Pekerjaan yang berhubungan dengan tanah termasuk petani sawah beresiko besar tertular infeksi cacing terutama nematoda usus STH yang dalam perkembangannya memerlukan tanah untuk menjadi stadium infektif (Alamsyah et al., 2018).

Spesies cacing yang masuk ke dalam golongan STH yaitu Ascaris lumbricoides (cacing gelang), Trichuris trichiura (cacing cambuk), dan cacing tambang (Ancylostoma duodenale dan Necator americanus). Infeksi STH tidak hanya dipengaruhi oleh satu faktor saja, melainkan beberapa faktor pendukung. Faktor tersebut dapat berasal dari hospes dan juga pengaruh kondisi lingkungan. Manusia dengan mudah terinfeksi akibat tidak sengaja menelan telur cacing yang masuk bersamaan mengkontaminasi makanan dan minuman. Tidak mencuci tangan usai bekerja kontak dengan tanah juga menjadi penyebab terinfeksi telur cacing, sedangkan larva pada cacing tambang dapat menginfeksi manusia melalui penetrasi kulit apabila terlalu lama kontak dengan 
tanah tanpa memakai APD seperti sepatu boot dan sarung tangan saat sedang bekerja (Umamah \& Nugroho, 2020).

Berdasarkan dari data World Health Organization (WHO) tahun 2016 menyebutkan bahwa lebih dari 1,5 milyar orang atau sekitar $24 \%$ penduduk dunia terinfeksi cacing nematoda usus STH. Kejadian infeksi STH terbesar terdapat di Afrika, Amerika serta Asia terutama negara India, China, dan Asia Tenggara. Indonesia berada di posisi ke-2 menjadi negara dengan kejadian infeksi STH tertinggi di Asia Tenggara. Kejadian infeksi tinggi di indonesia karena adanya iklim tropis dan juga kelembaban sehingga dapat mendukung penyebaran infeksi cacing (Saftarina et al., 2020).

Penelitian mikroskopis yang dilakukan dalam mengetahui infeksi cacing STH salah satunya di Kabupaten Kediri Jawa Timur prevalensi Ascaris lumbricoides pada petani sebesar 40\%, Trichuris trichiura dan Hookworm sebesar 0,025\%. (Apsari et al., 2020). Penelitian juga dilakukan kepada petani pengguna pupuk kandang di desa Rasau Jaya Umum tahun 2013 dengan prevalensi sebesar 13,9\% (Salim, 2013). Penelitian terhadap petani juga dilakukan di Desa Nusapati Sungai Pinyuh Kabupaten Mempawah didapatkan hasil prevalensi sebanyak 50,5\% responden petani yang terinfestasi STH (Nurfalq et al., 2016).

Menurut Saftarina (2018) pada penelitiannya menyatakan bahwa adanya hubungan antara personal higiene dan infeksi nematoda usus STH pada petani di desa Besuk. Kurang pedulinya masyarakat terhadap kebersihan kuku dan tangan saat makan, pemakaian alat pelindung diri seperti sepatu boot dan sarung tangan dan juga pemakaian pupuk kandang yang menyebabkan sebagian besar petani sawah terinfeksi cacing STH.

\section{METODE PENELITIAN}

Penelitian ini menggunakan jenis penelitian observasional dengan pendekatan cross sectional.

Tempat dan Waktu Penelitian : Penelitian dilakukan di Laboratorium Parasitologi Universitas Setia Budi Surakarta dari bulan Maret - April 2021.

Populasi : Populasi penelitian ini adalah 42 petani sawah yang ada di Desa MunggurKecamatan Manyaran Wonogiri.

Teknik Pengambilan Sampel : Teknik yang digunakan untuk mengambil sampel adalah simple random sampling.

Sampel : Sampel yang digunakan sebanyak 20 sampel feses dan 20 sampel kotoran kuku. 
Analisa Data Prosentase Infeksi STH: Analisa data dilakukan dengan perhitungan persentase hasil negatif dan positif.

$$
\frac{\text { Jumlah sampel positif STH }}{\text { jumlah sampel yang diperiksa }} \times 100 \%
$$

\section{Alat dan Bahan :}

Alat yang digunakan yaitu : pot sampel feses dan kotoran kuku, pemotong kuku, objek glass, deck glass, pipet tetes, tabung reaksi, rak tabung reaksi, mikroskop, beaker glass, sendok plastik.

Bahan yang digunakan yaitu : sampel feses dan sampel potongan kuku dari petani sawah, larutan $\mathrm{NaCl} 0,9 \%, \mathrm{NaOH} 0,25 \%$, larutan lugol 1-2\%.

\section{Persiapan Responden:}

Persiapan responden dalam pengambilan sampel feses dan kuku :

1. Menjelaskan dengan sikap ramah kepada petani untuk mengambil sampel feses dan potongan kuku yang akan diambil pada keesokan harinya menggunkan sendok plastik karena akan segera dibawa ke laboratorium untuk dilakukan pemeriksaan.

2. Peneliti membagikan kuisioner serta pot sampel feses dan potongan kuku dengan kode sampel yang dilengkapi sendok plastik serta pemotong kuku

3. Peneliti menjelaskan agar sampel feses yang sudah terkumpul segera dicampur dengan larutan $\mathrm{NaCl}$ 0,9\% yang sudah disiapkan oleh peneliti kemudian menutup dengan rapat dan memberitahu agar sendok plastik dibuang setelah digunakan, kemudian menjelaskan untuk memotong kuku yang panjang dan kotor.

\section{Prosedur Kerja Pemeriksaan Makroskopis Feses :}

1. Pot sampel feses dibuka secara perlahan

2. Pada pemeriksaan makroskopis memperhatikan hal hal berikut :

a. Warna : feses yang dibiarkan terlalu lama terkena udara warnanya akan berubah lebih tua akibat terbentuk urobilin lebih banyak dan urobilinogen yang di eksresi lewat usus

b. Bau : bau normal akibat adanya indol, skatol dan asam butirat

c. Konsistensi : feses normal memiliki konsistensi agak lunak dan berbentuk 
d. Darah : darah segar, coklat atau hitam yang terdapat pada feses dapat mengindikasikan adanya infeksi yang disebabakan parasit

e. Lendir : adanya lendir bisa menjadi indikasi adanya rangsangan atau radang dinding usus

f. Parasit : cacing nematoda usus golongan STH (Gandasoebrata, 2010).

\section{Prosedur Kerja Pemeriksaan Mikroskopis Feses:}

1. Obyeck glass dibersihkan menggunakan alkohol $70 \%$ kemudian dilap menggunakan tisue, dibiarkan kering dan beri kode identitas

2. Larutan lugol 1-2\% diteteskan sebanyak 1 tetes diatas obyeck glass

3. Sampel feses diambil seujung lidi dan diletakkan diatas obyeck glass

4. Sampel feses dan lugol 1-2\% dihomogenkan diatas objek glass

5. Preparat feses ditutup dengan deck glass perlahan agar tidak terjadi gelembung udara

6. Preparat yang sudah siap segera diperiksa dengan mikroskop lensa objektif perbesaran 100 dilanjutkan 400 (Sihombing \& Mulyowati, 2018).

\section{Prosedur Pemeriksaan Sampel Kotoran Kuku :}

1. Potongan kuku yang sudah terkumpul di dalam pot sampel kemudian diambil menggunakan pinset dan dimasukkan ke dalam tabung reaksi

2. Ditambahkan larutan $\mathrm{NaOH} 0,25 \%$ sebanyak $3 / 4$ kedalam tabung reaksi

3. Sampel kuku direndam dan diamkan selama 24 jam sebelum di sentrifugasi

4. Setelah 24 jam, tabung yang berisi potongan kuku dimasukkan ke dalam centrifuge dan setting dengan kecepatan 1.500 rpm selama 5 menit.

5. Buang supernatan dan diambil sedimen menggunakan pipet tetes

6. Larutan lugol 1-2\% diteteskan sebanyak 1 tetes di atas obyeck glass kemudian ambil 1 tetes sedimen kotoran kuku lalu homogenkan menggunakan lidi

7. Preparat ditutup dengan deck glass secara perlahan untuk menghindari gelembung udara

8. Preparat diamati menggunakan mikroskop dengan lensa obyektif perbesaran 100 dilanjutkan perbesaran 400 .

\section{INTERPRETASI HASIL}

(+) ditemukan adanya telur nematoda usus golongan Soil Transmitted Helminth

(-) tidak ditemukan adanya telur nematoda usus golongan Soil Transmitted Helminth (Prasetyo, 2012). 


\section{HASIL DAN PEMBAHASAN}

Secara umum cacing nematoda usus STH hidup di dalam usus manusia yang terinfeksi hingga bertelur dan telur akan keluar bersama dengan feses penderita. Pekerjaan yang berhubungan dengan tanah dapat beresiko terinfeksi nematoda usus STH. Petani memiliki peluang tiga kali lebih beresiko terkena infeksi cacing nematoda usus STH dibandingkan bukan petani (Apsari et al., 2020).

Penelitian ini dilakukan dengan pemeriksaan sampel feses dan kotoran kuku petani sawah di Desa Munggur, lokasi yang dipilih berdasarkan kondisi lingkungan dan faktor personal. Pemeriksaan pada sampel kuku dapat digunakan sebagai diagnosis awal untuk infeksi kecacingan kemudian dalam menegakkan infeksi nematoda usus STH yaitu dengan melakukan pemeriksaan feses, pemeriksaan feses bertujuan untuk menemukan adanya telur cacing nematoda usus STH pada feses penderita dikarenakan habitat cacing nematoda usus berada di dalam usus manusia (Rahmadhini \& Mutiara, 2015).

\section{Hasil Pemeriksaan Makroskopis}

Tabel 1. Hasil Pemeriksaan Makroskopis

\begin{tabular}{|c|c|c|c|c|c|c|}
\hline No sampel & Wama & Bau & Konsistensi & Darah & Lendix & Parasit \\
\hline 1 & Kuning kecoklatan & Khas & Lumak & - & - & - \\
\hline 2. & Kuning kecoklatan & Khas & Agak lumak & - & - & - \\
\hline 3. & Kuning kecoklatan & Khas & Lumak & - & - & - \\
\hline 4. & Kuning & Khas & Agak lunak & - & - & - \\
\hline 5. & Kuning kecoklatan & Khas & Agak lumak & - & - & - \\
\hline 6. & Kuning kecoklatan & Khas & Lumak & - & - & - \\
\hline 7. & Kuming & Khas & Agak lumak & - & - & - \\
\hline 8. & Kuning kecoklatan & Khas & Agak lumak & - & - & - \\
\hline 9. & Kuming & Khas & Lumak & - & - & - \\
\hline 10. & Kuning & Khas & Agak lumak & - & - & - \\
\hline 11. & Kuning kecoklatan & Khas & Agak lumak & - & - & - \\
\hline 12. & Kuning kecoklatan & Khas & Agak lumak & - & - & - \\
\hline 13. & Kuming kecoklatan & Khas & Agak lunak & - & - & - \\
\hline 14. & Kuming & Khas & Agak lunak & - & - & - \\
\hline 15. & Kuning kecoklatan & Khas & Lumak & - & - & - \\
\hline 16. & Kuning kecoklatan & Khas & Agak lumak & - & - & - \\
\hline 17. & Kuming kecoklatan & Khas & Agak lumak & - & - & - \\
\hline 18. & Kuning kecoklatan & Khas & Agak lunak & - & - & - \\
\hline 19. & Kuming kecoklatan & Khas & Lumak & - & - & - \\
\hline 20 . & Kuning kecoklatan & Khas & Agaklumak & - & - & - \\
\hline
\end{tabular}

Sebanyak 20 sampel feses dalam pemeriksaan makroskopis yang meliputi warna, bau, konsistensi darah, lendir dan parasit, 4 sampel feses berwarna kuning sisanya ada 16 sampel feses berwarna kuning kecoklatan dan 6 sampel feses memiliki konsistensi lunak sedangkan 14 sampel feses memiliki konsistensi agak lunak. Pemeriksaan makroskopis sampel feses tidak ditemukan adanya darah, lendir dan juga parasit.

\section{Hasil Pemeriksaan Mikroskopis}


Tabel 2. Hasil Pemeriksaan Mikroskopis Sampel Feses Dan Kotoran Kuku

\begin{tabular}{|c|c|c|c|c|c|}
\hline No sampel & Usia & Jenis kelamin & Kuku & Feses & Keterangan \\
\hline 1 & 63 & Laki-1aki & - & - & -1 \\
\hline 2. & 58 & Laki-1aki & - & - & - \\
\hline 3. & 50 & Laki-1aki & - & - & - \\
\hline 4. & 46 & Laki-1aki & - & - & - \\
\hline 5. & 63 & Laki-1aki & - & - & - \\
\hline 6. & 60 & Perempuan & - & - & - \\
\hline 7. & 65 & Perempuan & - & - & - \\
\hline 8. & 69 & Laki-1aki & - & - & - \\
\hline 9. & 68 & Laki-1aki & - & - & - \\
\hline 10 . & 44 & ILaki-1aki & - & - & - \\
\hline 11. & 76 & Laki-1aki & - & - & - \\
\hline 12. & 70 & Laki-1aki & - & + & Telur Hookworm \\
\hline 13. & 67 & Laki-1aki & - & + & Telur Hookworm \\
\hline 14. & 72 & ILaki-1aki & - & - & - \\
\hline 15. & 65 & Laki-1aki & - & - & - \\
\hline 16. & 59 & Perempuan & - & - & - \\
\hline 17. & 78 & Laki-1aki & - & - & - \\
\hline 18. & 75 & Laki-1aki & - & - & - \\
\hline 19. & 73 & Laki-1aki & - & - & - \\
\hline 20 & 70 & Laki-1aki & - & - & - \\
\hline
\end{tabular}

Sebanyak 20 sampel kuku tidak ditemukan adanya telur nematoda usus STH sedangkan pada sampel feses ditemukan adanya telur nematoda usus STH jenis Hookworm pada sampel feses nomor 12,13.

Tabel 3. Persentase Hasil Pemeriksaan Sampel feses

\begin{tabular}{lll}
\hline Hasil & Frekuensi & Persentase \\
\hline Positif & 2 & 10 \\
Negatif & 18 & 90 \\
\hline Jumlah & $\mathbf{2 0}$ & $\mathbf{1 0 0}$ \\
\hline & & \\
& & \\
& & \\
& & \\
& &
\end{tabular}

Gambar 1.Sampel feses 12 dan 13 telur Hookworm

Pemeriksaan secara mikroskopis digunakan untuk mengetahui adanya telur nematoda usus STH pada sampel feses maupun kotoran kuku. Pemeriksaan secara mikroskopis sampel feses yaitu dengan pelarut $\mathrm{NaCl}$ 0,9\% ditambah pewarna lugol 1-2\% Larutan $\mathrm{NaCl}$ 0,9\% atau larutan garam fisiologi selain murah dan mudah di dapatkan larutan ini juga bersifat isotonis serta memiliki berbagai manfaat di bidang medis dan laboratorium. Konsentrasi $0,9 \%$ memberikan sifat buffer yang dapat mempertahankan $\mathrm{pH}$ dalam suhu kamar. Larutan pengencer $\mathrm{NaCl}$ 0.9\% dapat melindungi sel biologi dari suhu rendah dan memberikan sumber energi selama penyimpanan karena tanpa penggunaan bahan pengencer, telur akan mengalami kerusakan dan mati selama penyimpanan (Ekaswati et al., 2017). Prinsip dari pemeriksaan metode langsung yaitu dengan mencampurkan feses dengan $\mathrm{NaCl}$ 0,9\% dan lugol 1-2\%. Pemeriksaan sampel feses secara mikroskopis ditemukan adanya telur Hookworm pada sampel nomor 12 dan 13. 
Berdasarkan hasil jawaban kuisioner pada petani sawah di Desa Munggur Kecamatan Manyaran Wonogiri sebagian besar petani sawah masih mengabaikan penggunaan alas kaki atau sepatu boot ditambah kebiasaan petani sawah tidak mencuci tangan dengan air bersih sebelum makan setelah kontak langsung dengan tanah, hal tersebut menjadi penyebab petani sawah di Desa Munggur Kecamatan Manyaran Wonogiri terinfeksi cacing nematoda usus. Menurut penelitian Parweni et al., (2018) terhadap petani sayur hijau di Desa Bug-Bug Kecamatan Lingsar Kabupaten Lombok Barat menyatakan bahwa akibat dari pekerjaan yang kontak langsung dengan tanah tanpa penggunaan APD, ditambah kurangnya kesadaran dalam menjaga personal hygiene dan sanitasi seperti kebiasaan defekasi di tanah, dan tidak mencuci tangan sebelum makan setelah kontak dengan tanah dapat tertular infeksi cacing nematoda usus STH karena tidak sengaja menelan telur cacing nematoda usus STH (Parweni et al., 2018).

Petani dapat terinfeksi larva Hookworm apabila kontak langsung dengan tanah tanpa menggunakan sepatu boot dan sarung tangan. Menurut Ali et al., (2016) pada penelitiannya terhadap petani di Kelurahan Maharatu Pekanbaru menyatakan bahwa akibat dari mengabaikan pemakaian sepatu boot dapat memicu terjadinya infeksi cacing Hookworm dimana larva menembus kulit yang tidak tertutupi (tanpa pelindung). Sepatu boot lebih baik digunakan daripada sandal karena sepatu boot dapat menutup keseluruhan kaki saat bekerja kontak langsung dengan tanah dibandingkan sandal yang hanya menutup bagian telapak kaki saja (Ali \& Affandi, 2016). Petani yang tidak menggunakan sarung tangan juga beresiko terkena infeksi cacing nematoda usus STH, pemakaian sarung tangan saat kontak dengan tanah dapat memutuskan rantai dari penularan infeksi cacing Hookworm karena sarung tangan mampu menutup seluruh bagian telapak tangan (Baidowi et al., 2019).

Infeksi cacing Hookworm pada manusia terjadi melalui penetrasi kulit dari larva filariform yang merupakan stadium infektif. Petani dapat terinfeksi apabila kontak langsung dengan tanah yang terkontaminasi telur atau larva filariform yang infeksius. Infeksi cacing Hookworm lebih banyak ditemukan di daerah pedesaan dengan pengaruh kondisi lingkungan dan sanitasi yang buruk. Perkembangan dan siklus hidup telur Hookworm dipengaruhi oleh tanah, larva infektif Hookworm dapat berkembang dengan baik pada suhu $25-32^{\circ} \mathrm{C}$. Tanah yang gembur akan memudahkan larva Hookworm mendapatkan oksigen dibandingkan dengan tanah liat. Tanah liat bersifat padat dan sedikit rongga udara sehingga tidak mencukupi kebutuhan oksigen yang diperlukan oleh mikroorganisme tanah (Indriyati et al., 2020). 
Tanah yang terkontaminasi telur cacing nematoda STH yang keluar bersamaan dengan feses penderita dalam waktu 2 hari telur berubah menjadi larva rabditiform (tidak infektif). Larva rabditiform yang berada di tanah selama 7 hari akan berkembang menjadi larva filariform (stadium infektif) (Soedarto, 2017). Penularan cacing tambang pada petani dapat melalui penetrasi kulit dimana larva filariform yang merupakan stadium infektif dari cacing tambang (Hookworm) akan menembus kulit manusia dan masuk ke pembuluh darah dengan menimbulkan reaksi gatal (ground itch) apabila larva migrasi ke paru menyebabkan pneumonitis.Infeksi lebih berat disebabkan cacing tambang jenis Ancylostoma duodenale daripada infeksi yang disebabkan cacing Necator americanus (Noviastuti, 2015).

Infeksi cacing Hookworm pada manusia dapat menyebabkan anemia karena cacing Hookworm berperan sebagai penyebab dari defisiensi zat besi di dalam tubuh manusia. Adanya kontaminasi tanah oleh telur maupun larva Hookworm dapat menularkan infeksi kepada petani lain.

Pemeriksaan mikroskopis pada sampel feses no 12 dan 13 ditemukan adanya telur Hookworm, hal ini juga dapat disebabkan karena beberapa faktor antara lain penggunaan kotoran hewan sebagai pupuk kandang yang mengakibatkan telur dengan mudah tersebar mengkontaminasi tanah dan menginfeksi manusia akibat bersentuhan langsung dengan tanah (Umamah \& Nugroho, 2020). Berdasarkan wawancara terhadap petani sawah di Desa Munggur Kecamatan Manyaran Wonogiri, dalam upaya untuk menyuburkan tanah lahan pertanian petani sering menggunakan pupuk kandang dari hewan sapi yang biasa digunakan sebagai pupuk organik. Pupuk organik menjadi alternatif dalam mengurangi penggunakan pupuk anorganik yang berlebihan. Namun, perlu diperhatikan dalam penggunaan pupuk organik dari kotoran hewan sapi yang secara langsung diaplikasikan pada tanaman tanpa pengolahan akan menyebabkan pencemaran lingkungan, kotoran sapi yang masih banyak kandungan air memliki potensi penularan bibit penyakit dan senyawa beracun (Arimurti et al., 2020).

Petani sawah di Desa Munggur Kecamatan Manyaran Wonogiri juga masih mengabaikan penggunaan sarung tangan saat bekerja kontak langsung dengan tanah. Berdasarkan daur hidup cacing nematoda usus STH jenis Hookworm, penularan terjadi melalui tanah yang terkontaminasi telur atau larva cacing tambang, telur yang jatuh dari feses penderita yang terinfeksi STH akan mengkontaminasi tanah dan dalam waktu 2 hari telur berubah menjadi larva rabditiform (tidak infektif). Larva rabditiform yang berada di tanah 
selama 7 hari akan berkembang menjadi larva filariform (stadium infektif) (Soedarto, 2017). Penularan cacing tambang pada petani dapat melalui penetrasi kulit dimana larva filariform yang merupakan stadium infektif dari cacing tambang (Hookworm) akan menembus kulit manusia dan masuk ke pembuluh darah dengan menimbulkan reaksi gatal (ground itch) apabila larva migrasi ke paru menyebabkan pneumonitis.Infeksi lebih berat disebabkan cacing tambang jenis Ancylostoma duodenale daripada infeksi yang disebabkan cacing Necator americanus (Noviastuti, 2015).

Hasil negatif yang didapatkaan pada sampel feses dan kotoran kuku petani sawah kemungkinan disebabkan karena beberapa petani memiliki daya tahan tubuh yang baik dengan rutin mengkonsumsi obat cacing setiap 6 bulan sekali, rutin memotong kuku seminggu sekali dan juga mencuci tangan setelah kontak dengan tanah. Mencuci tangan berguna dalam meminimalisir dan mematikan mikroorganisme yang melekat di tangan maupun kuku setelah melakukan aktivitas yang berhubungan dengan tanah (Dewi \& Nurdian, 2018). Menurut Alamsyah et al., (2018) mencuci tangan dengan air bersih saja tidak cukup efektif mengurangi penularan infeksi cacing dibandingkan dengan mencuci tangan memakai sabun. Mencuci tangan harus dilakukan dengan air bersih dan juga sabun untuk mencegah terjadinya infeksi cacing.

\section{KESIMPULAN}

a. Ditemukan adanya telur cacing nematoda usus STH yaitu telur Hookworm pada sampel feses no 12 dan 13 petani sawah di Desa Munggur Kecamatan Manyaran Wonogiri, kemudian pada pemeriksaan sampel kuku tidak ditemukan adanya telur cacing nematoda usus STH.

b. Persentase petani sawah di Desa Munggur Kecamatan Manyaran Wonogiri yang terinfeksi telur cacing nematoda usus pada sampel feses yaitu 10\%, kemudian persentase pada sampel feses yang tidak ditemukan adanya telur nematoda usus STH dinyatakan negatif sebesar $90 \%$ pada sampel feses petani sawah di Desa Munggur Kecamatan Manyaran Wonogiri.

\section{DAFTAR PUSTAKA}

Alamsyah, D., Saleh, I., \& Nurijah, N. (2018). Faktor Yang Berhubungan Dengan Kejadian Infeksi Soil Transmitted Helminths (Sth) Pada Petani Sayur Di Desa Lingga Kecamatan Sungai Ambawang Kabupaten Kubu Raya Tahun 2017. JUMANTIK Jurnal, 2-7. http://openjurnal.unmuhpnk.ac.id/index.php/JJUM/article/view/858

Ali, R. U., \& Affandi, D. (2016). Hubungan Personal Hygiene dan Sanitasi Lingkungan dengan Angka Kejadian Kecacingan ( Soil Transmitted Helminth ) Pada Petani Sayur di Kelurahan 
Maharatu Kecamatan Marpoyan Damai Kota Pekanbaru. 3, 24-33.

Apsari, P. I., Budi, Winianti, N. W., Arwati, H., Dachlan, Y. P., \& Universitas, F. K. (2020). Gambaran Infeksi Soil Transmitted Helminth Pada Petani DI Desa Gelgel Kabupaten Klungkung. Jurnal Lingkungan Dan Pembangunan, 4(2).

Arimurti, A. R. R., Merinda, V. F., \& Zhro, F. (2020). Gambaran Parasit Ccaing Nematoda Usus dan Cestoda Pada Feses Sapi (Boss sp) di Peternakan Sumber Jaya Ternak, Kecamatan Tikung, Kabupaten Lamongan Jawa Timur. The Journal Of Muhammadiyah Medical Laboratory Technologist, 3(1), 39-52.

Baidowi, I. I., Armiyanti, Y., Febianti, Z., Hermansyah, B., \& Nurdian, Y. (2019). The Correlation Between The Use of Personal Protective Equipment ( PPE ) and Soil- Transmitted Helminths Infection in the Workers of Kaliputih Plantation Jember Regency. Journal of Agromedicine and Medical Science, 5(2), 61-68.

Dewi, F. M. K., \& Nurdian, Y. (2018). Faktor Risiko Petani Sayuran terhadap Infestasi SoilTransmitted Helminths. 2-4.

Ekaswati, Suhardono, DH, S., DA, D., AH, W., \& E, M. (2017). Media Penyimpanan Telur, Larva dan Cacing Nematoda sebagai Media Uji In Vitro ( Storage Medium of Eggs, Larvae and Adult Nematode Worms as In Vitro Medium ) berada . 693-701.

Gandasoebrata. (2010). Penuntun Laboratorium Klinik. Dian Rakyat.

Indriyati, L., Hairani, B., \& Fakhrizal, D. (2020). Kontaminasi Telur Dan Larva Cacing Usus Pada Tanah Di Desa Juku Eja Kabupaten Tanah Bumbu. Jurnal Kesehatan Lingkungan Indonesia, $19(2), 127-132$.

Noviastuti, A. R. (2015). Infeksi Soil Transmitted Helminths. Majority, 4(8), 107-116.

Nurfalq, D. K. F., Saleh, I., \& Rochmawati. (2016). Hubungan Karakteristik Individu, Sanitasi Lingkungan Rumah, Personal Hygiene, Penggunaan APD dan Lama Bekerja Dengan Kejadian Infestasi STH. Fakultas Ilmu ..., 26. http://repository.unmuhpnk.ac.id/311/

Parweni, A. K. N., Getas, W. I., \& Zetun, S. (2018). Infeksi Kecacingan Nematoda Usus Yang Ditularkan Melalui Tanah ( Soil Transmitted Helminth ) Pada Petani Sayur Sawi Hijau Di Desa. Jurnal Analis Medika Bio Sains, 5(2).

Prabandari, A. S., Ariwarti, valentina D., Pradistya, R., \& Sari, M. M. S. (2020). Prevalensi Soil Transmitted Helminthiasis Pada Siswa Sekolah Dasar Di Kota Semarang. Jurnal of Health Research, 3(1), 1-10.

Prasetyo, R. . (2012). Pengantar Praktikum Helmintologi Kedokteran. Airlangga University Press.

Rahmadhini, S. N., \& Mutiara, H. (2015). Pemeriksaan Kuku sebagai Pemeriksaan Alternatif dalam Mendiagnosis Kecacingan Nail Inspection As an Alternative Examination in Diagnosing Worm Infections. Majority, 4(9), 113-117.

Saftarina, F., Hasan, M., Suwandi, J. F., \& Syani, A. Y. (2020). Kejadian infeksi soil-transmitted helminth pada petani. Jurnal Kedokteran Syiah Kuala, 20(3), 167-171. https://doi.org/10.24815/jks.v20i3.18732

Salim, M. (2013). Faktor-Faktor Yang Berhubungan Dengan Positif Telur Cacing Soil Transmitted 
Helminth ( STH ) Pada Petani Pengguna Pupuk Kandang Di Desa Rasau Jaya Umum Tahun 2013. Jurnal Laboratorim Khatulistiwa, 1(1), ISSN 2597-29523.

Sihombing, F. U., \& Mulyowati, T. (2018). Identifikasi Telur Cacing Hookworm , Toxocara vitulorum. Jurnal BIOMEDIKA, 11(02), 11-13.

Soedarto. (2017). Atlas dan Daur Hidup Parasitolohi Kedokteran Helmintologi dan Protozoologi (edisi pert). Jakarta: Sagung Seto.

Umamah, S., \& Nugroho, R. B. (2020). Prevalensi Nematoda Usus Golongan Soil Transmitted Helminth (STH) Pada Kuku dan Feses Petani Sayuran di Desa Ngagrong Kecamatan Ampel Kabupaten Boyolali. Journal of Health (JoH), 7(2), 59-64. https://doi.org/10.30590/joh.v7i2.190 